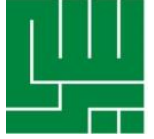

\title{
Meningkatkan Kepuasan Perkawinan Melalui Aktivitas Menghitung Kebaikan
}

\section{Increasing Marital Satisfaction Through Counting Kindess Activity}

\author{
Ratih Andrini ${ }^{1}$, Imelda Ika Dian Oriza ${ }^{2}$, Made Cynthia Agrita Putri \\ Rizwari $^{3}$, Mustika Nur Rafidasari ${ }^{4}$ \\ ${ }^{1,2,3,4}$ Fakultas Psikologi, Universitas Indonesia, Depok \\ Email:amdriniratih@gmail.com
}

\section{KATA KUNCI KEYWORDS}

ABSTRAK
ABSTRACT menghitung kebaikan, kepuasan perkawinan, hubungan

romantis

counting kindness, marital satisfaction, romantic relationship

Ketidakpuasan dalam perkawinan tidak hanya berdampak pada hubungan perkawinan, tetapi juga pada diri individu, seperti menurunnya kesehatan psikologis dan peningkatan stres psikologis dan kecenderungan depresi. Tujuan dari penelitian ini adalah menguji efektivitas aktivitas menghitung kebaikan dalam meningkatkan kepuasan perkawinan. Partisipan dalam penelitian ini berjumlah 62 orang yang terbagi menjadi dua kelompok, yaitu kelompok eksperimen dan kelompok kontrol. Kelompok eksperimen diminta untuk melaporkan kebaikan yang ia lakukan kepada pasangannya selama 7 hari berturut-turut. Kepuasan perkawinan partisipan diukur sebanyak 2 kali (pre-test dan post-test), dengan menggunakan Enrich Marital Satisfaction (EMS) yang sudah diadaptasi ke dalam Bahasa Indonesia. Hasil penelitian menunjukkan tidak terdapat perbedaan tingkat kepuasan perkawinan yang signifikan antara kelompok yang melakukan aktivitas menghitung kebaikan dan yang tidak melakukan aktivitas menghitung kebaikan. Akan tetapi, partisipan pada kelompok eksperimen menunjukkan tingkat kepuasan perkawinan yang meningkat sesudah melakukan aktivitas menghitung kebaikan, walaupun tidak signifikan.

Dissatisfaction in marriage does not only affect marital relationship, but also with individuals, such as decreased of psychological health and increased of psychological stress, and tendencies for depression. This study was conducted to examine the effectiveness of counting kindness activity in increasing marital satisfaction. Sixty-two married people was assigned into two different groups that are experimental group and control group. The experimental group was asked to report kindess that they did to their partner for 7 days. Marital satisfaction was measured 2 times (pre-test and post-test) using Enrich Marital Satisfaction (EMS) which was adapted in Bahasa.The results showed that there was no significant difference in the level of marital satisfaction between experimental group and control group. However, participants in the experimental group showed an increased level of marital satisfaction after doing counting kindess activity, although not significant. 


\section{PENDAHULUAN}

Bagi sebagian besar individu, perkawinan adalah sumber dari kepuasan dan pemenuhan kebutuhan dalam hidup (Karney \& Bradburry, 1995). Akan tetapi, apabila hubungan perkawinan tidak dapat berjalan dengan baik, perkawinan tersebut dapat berujung dengan frustrasi (Karney \& Bradburry, 1995), atau bahkan perceraian. Awalnya, keberhasilan dari suatu perkawinan dilihat dari berapa lama hubungan pasangan suami dan istri bertahan, namun perubahan nilai berhasil merubah fokus kesuksesan perkawinan yang awalanya berfokus pada durasi menjadi kualitas perkawinan (Duffy \& Atwater, 2005). Dengan memiliki kualitas hubungan perkawinan yang baik, individu berpotensi memiliki kesehatan fisik dan kesejahteraan psikologis yang lebih baik (Ahangar, Juhari, Yaacob, \& Talib, 2016). Kualitas hubungan tersebut dapat dilihat dari kebahagiaan, kenikmatan, cinta, afeksi, intimasi, komunikasi yang kuat, kelembutan, komitmen, dan kepuasan perkawinan (Ahangar, dkk, 2016).

Kepuasan perkawinan merupakan penilaian subjektif mengenai perasaan puas, bahagia, dan pengalaman menyenangkan pada individu yang berkaitan dengan keseluruhan aspek dalam perkawinan (Olson \& DeFrain, 2006). Tidak jauh berbeda, Stone dan Shackelford (2007) mendefinisikan kepuasan perkawinan sebagai keadaan mental yang merefleksikan manfaat dan usaha yang dirasakan individu di dalam perkawinannya. Kepuasan perkawinan juga meliputi dukungan dan pengertian secara emosional, kemandirian, penyelesaian masalah, dan resolusi konflik (Greeff \& Bruyne, 2000). Apabila pasangan tidak dapat menjaga elemen-elemen tersebut di dalam hubungan perkawinannya, maka kualitas perkawinan mereka dapat memburuk dan berpotensi menimbulkan berbagai masalah, seperti perselingkuhan, konflik pernikahan, ketidakpuasan seksual, komunikasi yang buruk, kecemasan, dan depresi (Greeff \& Bruyne, 2000).

Terdapat beberapa faktor yang dapat menentukan tinggi atau rendahnya kepuasan perkawinan yang dimiliki oleh individu. Hal tersebut terbagi menjadi kedalam dua masa, yaitu masa sebelum perkawinan dan masa sesudah perkawinan (Duvall \& Miller, 1985). Kebahagiaan perkawinan orang tua, kebahagiaan pada masa kanak-kanak, tingkat pendidkan, pendidikan seks yang diberikan oleh orang tua, dan masa mengenal pasangan sebelum menikah dapat mempengaruhi kepuasan perkawinan, walaupun hal tersebut terjadi sebelum perkawinan berlangsung (Duvall \& Miller, 1985). Saat sudah memasuki lembaga perkawinan, kebebasan dalam mengekspresikan cinta, kepercayaan dan saling mengandalkan satu sama lain, cara pengambilan keputusan dan pemecahan masalah pada hubungan, dan kebebasan dan keterbukaan dalam komunikasi emosional, sosial, dan seksual dapat mempengaruhi kepuasan perkawinan (Duvall \& Miller, 1985). Walaupun masa lalu cukup memiliki peranan dalam menentukan kepuasan perkawinan yang dimiliki oleh individu, namun tidak ada yang dapat dilakukan untuk mengubah masa lalu, kecuali dengan mencoba untuk memahami latar belakang satu sama lain di masa sekarang.

Berdasarkan penelitian yang dilakukan oleh Kaslow dan Hammerschmidt (1995, dalam Kaslow \& Robinson, 1996) di Swedia, ditemukan bahwa kepuasan perkawinan paling tinggi yang dirasakan oleh pasangan adalah pada saat keduanya saling sepakat mengenai filosofi kehidupan yang diyakini, konsep mengenai hubungan seksual yang memuaskan, durasi waktu berkualitas yang dihabiskan bersama atau pun masingmasing, dan frekuensi pertengkaran. Berdasarkan hasil penelitian tersebut, terlihat bahwa interaksi dengan pasangan sangat menentukan kepuasan perkawinan yang dimiliki oleh indivdiu, walaupun terdapat pula faktor-faktor lain di luar relasi 
dengan pasangan yang dapat mempengaruhi kepuasan perkawinan.

Menurut Stone dan Shackelford (2007), terdapat lima komponen di dalam kepuasan perkawinan, yaitu: (1) kognisi. Kognisi berperan dalam menentukan apakah perilaku yang ditampilkan pasangan dianggap sebagai sesuatu yang merugikan atau bermanfaat. Kepuasan perkawinan dapat menurun apabila individu menghubungan perilaku pasangan sebagai sesuatu yang merugikan. (2) Fisiologis. Terdapat hubungan yang kuat antara individu yang sudah menikah dan mempertahankan kebugaran fisik. Berdasarkan hasil penelitian individu yang lebih rajin berolahraga lebih merasa puas dengan hubungannya dibandingkan dengan tidak rajin berolahraga. (3) Pola interaksi. Pola interaksi antar pasangan dapat memengaruhi kepuasan perkawinan, seperti misalnya adanya tuntutan dari salah satu pihak yang berujung dengan penarikan diri atau menghindar dari pasangan yang lainnya dapat berdampak pada menurunnya kepuasan perkawinan. (4) Dukungan sosial. Dukungan sosial berhubungan dengan fungsi perkawinan yang baik dan situasi keluarga yang sehat. Individu yang dapat memberikan dukungan sosial dengan baik kepada pasangannya dapat meningkatkan kepuasan perkawinan pada pasangannya tersebut. (5) Kekerasan. Adanya kekerasan fisik di dalam hubungan perkawinan berpotensi membuat individu di dalam perkawinan tersebut merasa tidak puas dengan hubungan perkawinannya.

Ketidakpuasan dalam perkawinan sering kali menyebabkan inividu mengalami stres terkait hubungannya dan munculnya kecenderungan untuk bercerai yang lebih besar (Prasetya, 2001). Kepuasan perkawinan yang rendah tidak hanya berdampak kepada relasai antar pasangan, tetapi juga kepada individu itu sendiri. Kualitas perikahan yang buruk berpotensi membuat individu mengalami penurunan kesehatan psikologis dan peningkatan stres psikologis (Ross, Mirowsky, \& Goldsteen, 1990), dan berkorelasi pula dengan meningkatnya depresi (Dehle \& Weiss, 1998). Sebaliknya, perkawinan yang memuaskan cenderung dapat membuat pasangan terhindari dari tekanan psikologis dan pengalaman negatif lainnya (Karney \& Bradbury, 1995). Oleh karena itu, kepuasan perkawinan menjadi sangat penting, selain untuk menjaga keharmonisan pernikahan (Prasetya, 2001), memiliki kepuasan perkawinan yang tinggi juga berkontribusi pada kesehatan psikologis individu.

Berdasarkan pemaparan yang sudah disebutkan sebelumnya, tergambarkan memiliki kepuasan perkawinan yang tinggi dapat berdampak positif, baik kepada hubungan perkawinan maupun kepada individu itu sendiri. Oleh karena itu, menjadi suatu hal yang penting untuk meningkatkan kepuasan perkawinan, khususnya pada individu yang memiliki kepuasan perkawinan yang rendah. Salah satu cara yang dapat dilakukan untuk meningkatkan kepuasan perkawinan adalah dengan melakukan intervensi psikologi positif atau aktivitas positif.

Intervensi psikologi positif, atau yang biasa disebut juga dengan aktivitas positif, merupakan praktik kegiatan sederhana yang dilakukan dengan teratur dan sengaja untuk membentuk pengalaman sehat dan perilaku-perilaku tertentu sebagaimana yang dimiliki oleh orangorang bahagia (Lyubomirsky \& Layous, 2013). Tidak jauh berbeda, Sin dan Lyubomirsky (2009) mendefinisikan aktivitas positif sebagai metode perlakuan atau aktivitas yang dilakukan untuk memupuk perasaan positif, perilaku, dan kognisi yang positif. Aktivitas positif itu sendiri mulai dikembangkan ke dalam beberapa bentuk, yaitu menghitung berkat (counting blessings) (Emmons \& McCullough, 2003), membayangkan versi ideal dari diri sendiri (visualize ideal future selves) (Sheldon \& Lyubomirsky, 2006), mengekspresikan rasa syukur (expressing gratitude) (Seligman, Steen, Park, \& Peterson, 2005), dan menghitung kebaikan (counting kindness) (Otake, Tanaka- 
Matsumi, Otsui, \& Fredrickson, 2006). Menghitung kebaikan merupakan aktivitas positif yang diteliti baru-baru ini.

Aktivitas positif terbukti secara signifikan dapat meningkatkan kesejahteraan diri individu dan menurunkan gejala depresi (Sin \& Lyubomirsky, 2009; Bolier, Haverman, Westerhof, Riper, Smit, \& Bohlmeijer, 2013). Berdasarkan hasil penelitian sebelumnya, ditemukan bahwa dengan melakukan tindakan yang baik kepada orang lain, individu dapat merasa lebih bahagia, sejahtera, dan puas terhadap hidupnya (Kerr, O’Donnovan, \& Pepping, 2015; Buchanan \& Bardi, 2010; Lyubomirsky, Sheldon, \& Schkade, 2005). Selain itu, tindakan baik juga dapat membantu inividu dalam memenuhi kebutuhan dasarnya dalam membangun relasi dengan orang lain (Baumeister \& Leary, 1995). Penelitian yang dilakukan oleh Otake, dkk. (2006) menunjukkan bahwa tindakan sederhana berupa mengingat-ingat tindakan baik yang dilakukan kepada orang lain, membuat individu tersebut lebih bahagia dan bersyukur. Aktivitas mengingat kebaikan yang dilakukan kepada orang lain ini merupakan menghitung kebaikan (counting kindess).

Pada penelitian yang dilakukan oleh Gander, Proyer, Ruch, dan Wyss (2013), ditemukan bahwa kelompok yang melakukan aktivitas menghitung kebaikan mengalami peningkatan dalam kebahagiaan dan penuruan pada gejala depresi setelah melakukan aktivitas tersebut. Tidak jauh berbeda, penelitian yang dilakukan oleh Kerr, O'Donovan, dan Pepping (2015) menunjukkan bahwa kelompok yang melakukan aktivitas menghitung kebaikan memiliki kepuasan hidup yang lebih tinggi, lebih terhubung dengan orang lain, meningkatnya optimisme, dan memiliki tingkat kecemasan yang lebih rendah dibandingkan dengan kelompok kontrol.

Kebaikan adalah kekuatan karakter yang menggambarkan kecenderungan individu untuk berperilaku baik kepada orang lain, seperti beberbelas kasih, memberi bantuan, menjaga, dan memberikan perhatian kepada kesejahteraan orang lain (Peterson \& Seligman, 2004). Dengan kata lain, kebaikan adalah perilaku yang bermanfaat bagi orang lain atau dapat membuat orang lain bahagia (Kerr, O'Donnovan, \& Pepping, 2015). Menurut teori evolusi, individu cenderung mau melakukan kebaikan kepada orang terdekatnya. Sosok yang paling dekat dengan individu yang sudah memasuki hubungan perkawinan adalah pasangannya sendiri.

Kemurahan hati yang ditunjukkan dengan melakukan tindakan baik kepada pasangan secara rutin dapat membangun hubungan perkawinan yang baik. Berbuat baik kepada pasangan diasosiasikan dengan kepuasan hubungan yang lebih baik (Pasch \& Bradbury, 1998). Hal tersebut juga didukung dengan hasil penelitian yang dilakukan oleh Dew dan Wilcox (2011), dimana ditemukan bahwa kebaikan berkorelasi positif dengan kepuasan perkawinan dan berkorelasi negatif dengan konflik perkawinan dan perceraian.

Kebaikan itu sendiri banyak dihubungan dengan kepuasan perkawinan pada beberapa penelitian. Pada penelitian yang dilakukan oleh Kaslow dan Hammerschmidt (1993), ditemukan bahwa saling memberi dan menerima dengan pasangan merupakan salah satu unsur penting penentu kepuasan perkawinan dalam jangka panjang. Lebih jauh lagi, kebaikan dan kepuasan perkawinan dihubungkan melalui persepsi individu mengenai sejauh mana pasangannya responsif dan peduli, yang mana hal ini diasosiasikan dengan kepuasan perkawinan (Miller, Caughlin, \& Huston, 2003).

Berdasarkan

pemaparan sebelumnya, dapat disimpulkan bahwa melakukan kebaikan, khususnya kepada pasangan, berhubungan dengan kepuasan perkawinan. Oleh karena itu, peneliti akan melakukan penelitian uji eksperimental kepada sejumlah individu yang menikah untuk melaksanakan aktivitas menghitung kebaikan. Penelitian ini bertujuan untuk 
menguji efektivitas menghitung kebaikan dalam meningkatkan kepuasan perkawinan pada individu yang menikah. Peneliti memiliki dua hipotesis dalam penelitian ini, yaitu (1) terdapat perbedaan kepuasan perkawinan yang signifikan antara kelompok yang melakukan aktivitas menghitung kebaikan dan kelompok kontrol, dan (2) terdapat perbedaan kepuasan perkawinan yang signifikan sebelum dan sesudah melakukan aktivitas menghitung kebaikan.

\section{METODE PENELITIAN}

Penelitian ini tergolong ke dalam tipe eksperimen dengan desain kelompok kontrol pretest-posttest yang dirandomisasi (randomized pretest-posttest control group). Peneliti menggunakan desain dua kelompok untuk mencari tahu pengaruh efektivtas menghitung kebaikan terhadap kepuasan perkawinan, yaitu terdiri dari kelompok eksperimen (KE) dan kelompok kontrol (KK) sebagai pembanding. Kriteria partisipan dalam penelitian ini adalah (1) rentang usia pernikahan 1-13 tahun, (2) tinggal serumah dengan pasangan, (3) sudah lulus kuliah (D3/S1 atau sederajat). Partisipan dalam penelitian ini berjumlah 62 orang dan dibagi menjadi dua kelompok, yaitu 31 orang untuk KE dan 31 orang untuk KK.

Teknik yang digunakan untuk mengambil sampel adalah non-probability sampling, karena jumlah populasinya tidak diketahui secara jelas dan peneliti tidak dapat memperoleh data dari anggota populasi (Gravetter \& Forzano, 2009). Metode non-probablily sampling yang digunakan adalah convenience sampling, dimana peneliti mencari partisipan yang mudah untuk didapatkan dan berdasarkan kesediaan dan keinginan partisipan untuk berpartisipasi dalam penelitian (Gravetter \& Forzano, 2009). Perekrutan partisipan dilakukan dengan menyebarkan informasi mengenai penelitian melalui poster dan pesan singkat di media sosial. Lima partisipan beruntung yang mengikuti penelitian secara lengkap, yaitu selama lima minggu, akan mendapatkan hadiah kupon belanja sebesar Rp. 500.000,00 untuk masing-masing partisipan secara diundi.

Kelompok KE dan KK akan mendapatkan dua kali pengukuran, yaitu pretest dan posttest, untuk mengukur kepuasan perkawinan dengan menggunakan Enrich Marital Satisfaction (EMS) (Fower \& Olson, 1993) yang sudah diadaptasi ke dalam bahasa indonesia oleh Juwita (2013). EMS terdiri dari 16 aitem dengan 6 poin skala likert $(1=$ sangat tidak puas, $6=$ sangat puas). EMS memiliki koefisien alpha sebesar 0,908. Pretest dilakukan dua minggu sebelum aktivitas menghitung berkat dilakukan, sedangkan posttest dilakukan dua minggu setelah aktivitas menghitung berkat selesai dilakukan.

Dalam penelitian ini, kelompok eksperimen akan diminta untuk mengingatingat tindakan baik yang telah mereka lakukan kepada pasangan setiap harinya, lalu membuat daftar tindakan baik tersebut pada tautan yang sudah diberikan di antara pukul 19.00 sampai dengan pukul 22.00 WIB setiap harinya. Aktivitas tersebut dilakukan selama seminggu dan tidak ada batasan jumlah daftar yang harus dilaporkan dalam sehari. Pada hari terakhir, partisipan juga diminta untuk menilai sejauh mana aktivitas menghitung kebaikan berdampak positif terhadap relasinya dengan pasangan.

Pengujian hasil hipotesis dilakukan dengan membandingkan selisih skor sebelum dan sesudah melakukan aktivitas menghitung kebaikan antar kelompok. Dengan melihat selisih skor, dapat diketahui apakah aktivitas menghitung kebaikan berpengaruh terhadap kepuasan perkawinan. Data hasil penelitian dianalisis dengan menggunakan uji Independent T-test.

\section{ANALISIS \& HASIL}

Partisipan dalam penelitian ini berjumlah 62 orang, terdiri dari 10 orang laki-laki $(16,12 \%)$ dan 52 orang perempuan $(83,87 \%)$, dengan rata-rata usia partisipan 
adalah 28,98 tahun $(\mathrm{SD}=3,99)$. Partisipan memiliki pendidikan yang bervariasi, yaitu diploma $(4,83 \%)$, sarjana $(74,19 \%)$, dan pascasarjana $(20,96 \%)$. Seluruh partisipan sudah menikah dengan rata-rata usia perkawinan partisipan adalah 4 tahun 5 bulan $(\mathrm{SD}=2,93)$ dan rata-rata jumlah anak yang dimiliki oleh tiap partisian adalah satu orang. Seluruh partisipan dibagi menjadi dua kelompok, yaitu kelompok kontrol (KK) dan kelompok eksperimen (KE), dengan masing-masing kelompok memiliki jumlah dan proporsi partisipan yang sama, yaitu partisipan laki-laki berjumlah 5 orang dan perempuan berjumlah 26 orang.
KE melakukan aktivitas menghitung kebaikan selama seminggu penuh dan melaporkan rata-rata tiga kebaikan dalam satu hari. Terkait variabel kepuasan perkawinan, KE menunjukkan skor kepuasan perkawinan yang meningkat antara sebelum $(\mathrm{M}=78,03, \mathrm{SD}=8,11)$ dan sesudah $(\mathrm{M}=78,74, \mathrm{SD}=9,68)$ melakukan aktivitas menghitung kebaikan. Sebaliknya, pada KK, skor kepuasan perkawinan mengalami penurunan antara pengukuran pertama $(\mathrm{M}=79,61, \quad \mathrm{SD}=10,99) \quad$ dan pengukuran kedua $(\mathrm{M}=79,13, \mathrm{SD}=10,13)$.

Tabel 1

Skor rata-rata, standar deviasi, dan signifikansi variabel kepuasan perkawinan

\begin{tabular}{|c|c|}
\hline $\mathrm{KK}(\mathrm{M}, \mathrm{SD})$ & $\mathrm{KE}(\mathrm{M}, \mathrm{SD})$ \\
\hline $79,61(10,99)$ & $78,03(8,11)$ \\
\hline $79,13(10,13)$ & $78,74(9,68)$ \\
\hline $\begin{array}{l}\text { Dalam menguji hipotesis pertama, peneliti } \\
\text { melakukan uji normalitas terlebih dahulu } \\
\text { dengan menggunakan Kolmogorov- } \\
\text { Smirnov, hasilnya menunjukkan bahwa } \\
\text { data pada kedua kelompok berdistribusi } \\
\text { normal, dimana kelompok aktivitas } \\
\text { menghitung kebaikan } \mathrm{D}(31)=0,11, \mathrm{p}>0,05 \\
\text { dan kelompok kontrol } \mathrm{D}(31)=0,11, \mathrm{p}>0,05 \text {. } \\
\text { Hasil analisis data menunjukkan bahwa } \\
\text { tidak terdapat persamaan varians antara KE } \\
\text { dan KK terhadap kepuasan perkawinan } \\
\mathrm{F}(1,60)=4,42 \text {, p }<0,05 \text {. Walaupun varians } \\
\text { tidak homogen, namun data tetap } \\
\text { terdistribusi secara normal, sehingga dapat }\end{array}$ & 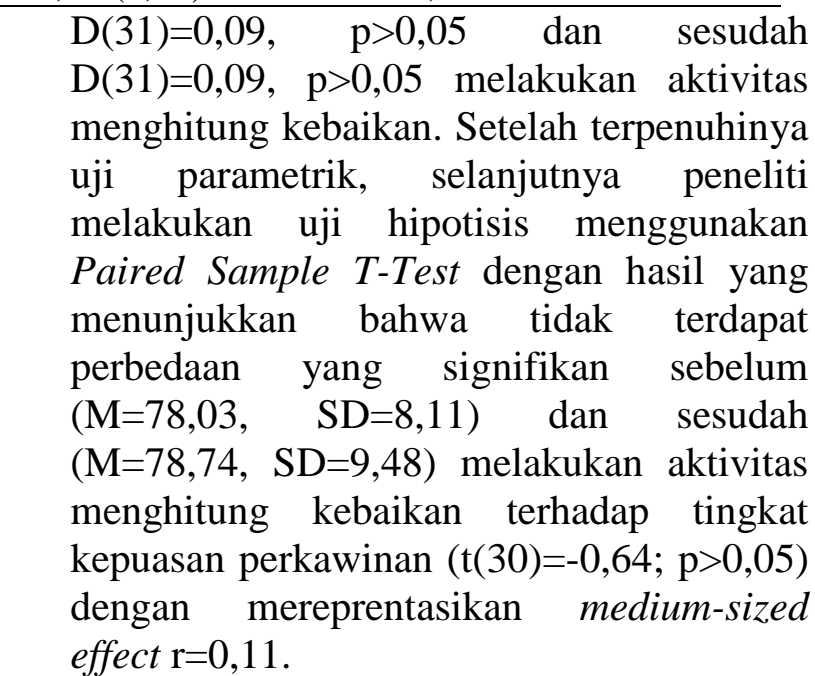 \\
\hline
\end{tabular}
menggunakan Independent Sample T-Test dalam menguji hipotesis. Hasil uji Independent Sample T-Test menunjukkan bahwa tidak terdapat perbedaan yang signifikan antara $\mathrm{KE}(\mathrm{M}=0,71, \mathrm{SD}=6,15)$ dan $\mathrm{KK} \quad(\mathrm{M}=-0,48, \quad \mathrm{SD}=3,63)$ terhadap tingkat kepuasan pernkawinan $(\mathrm{t}(60)=0,356 ; \quad \mathrm{p}>0,05), \quad$ dengan merepresentasikan small-sized effect $\mathrm{r}=0,04$.

Dalam menguji hipotesis kedua, peneliti melakukan uji normalitas terlebih dahulu dengan menggunakan KolmogorovSmirnov, hasilnya menunjukkan bahwa data terdistribusi secara normal sebelum

\section{DISKUSI}

Temuan dalam penelitian ini menunjukkan bahwa tidak terdapat perbedaan tingkat kepuasan perkawinan yang signifikan pada kelompok yang melakukan aktivitas menghitung kebaikan dan yang tidak melakukan aktivitas menghitung kebaikan (hipotesis 1). Selain itu, ditemukan pula bahwa tidak terdapat perbedaan tingkan kepuasan perkawinan yang signifikan sebelum dan sesudah melakukan aktivitas menghitung kebaikan (hipotesis 2). Berdasarkan hasil temuan 
tersebut, kedua hipotesis yang dibangun pada awal penelitian ditolak. Peneliti memiliki dugaan mengapa kedua hipotesis dalam penelitian ini ditolak, yaitu (1) dibutuhkan waktu yang panjang untuk mengubah kepuasan perkawinan, (2) minimnya interaksi dengan pasangan, (3) kebingungan partisipan dalam membedakan kebaikan dan kewajiban, (4) faktor anak, (5) merasa kebaikan yang dilakukan masih sedikit, dan (6) kesesuaian individu dengan aktivitas menghitung kebaikan.

Kepuasan perkawinan adalah penilaian subjektif mengenai perasaan puas, bahagia, dan pengalaman menyenangkan yang berkaitan dengan keseluruhan aspek dalam perkawinan (Olson \& DeFrain, 2006). Oleh karena itu, dibutuhkan waktu yang cukup panjang untuk dapat mengubah penilaian atau evaluasi mengenai kepuasan perkawinan. Penelitian longitudinal menemukan bahwa rata-rata kepuasan perkawinan dapat berubah dalam kurun waktu tahunan (Stone \& Shackleford, 2007). Hal tersebut dapat menjadi alasan mengapa kepuasan perkawinan tidak mengalami perubahan yang signifikan dalam penelitian ini, mengingat partisipan hanya diminta melakukan aktivitas menghitung kebaikan selama satu minggu.

Adanya pasangan yang bekerja, baik salah satunya maupun keduanya, membuat minimnya interaksi yang dilakukan oleh pasangan. Cukup banyak partisipan yang mengatakan bahwa ia dan/atau pasangannya bekerja dari pagi hari hingga larut malam. Partisipan yang kurang berinteraksi dengan pasangannya merasa kesulitan untuk menghitung kebaikan karena intensitas bertemu dengan pasangan yang sedikit (Stone \& Shackleford, 2007).

Persepsi mengenai tindakan baik dapat berpengaruh pada penelitian ini. Terdapat beberapa partisipan yang merasa kebingungan dalam membedakan antara tindakan baik dan kewajiban sebagai suami/istri. Banyak kegiatan rutin yang mereka lakukan sehari-hari dan kegiatan tersebut dianggap sebagai kewajiban, seperti menyiapkan sarapan, menjaga anak, membereskan rumah, mengatur keuangan rumah tangga, bekerja untuk mencari uang, dan lain sebagainya. Saat tindakan baik sudah sering dilakukan sehari-hari, individu akan merasa tindakan tersebut tidak spesial, khususnya apabila hal tersebut sudah dianggap sebagai kewajiban suami/istri. Tidak hanya itu, saat perilaku sudah menjadi kebiasaan, usaha individu untuk mengingat hal tersebut atau menghitungnya sebagai kebaikan pun akan berkurang, padahal aktivitas menghitung kebaikan adalah aktivitas kognitif yang pengaruhnya bergantung pada usaha seseorang untuk mengingat kebaikannya (the role of effort) (Lyubomirsky, Sheldon, \& Schkade, 2005).

Anak dapat mempengaruhi tingkat kepuasan perkawinan secara negatif (Rollins \& Feldman, 1970). Rata-rata partisipan dalam penelitian ini memiliki satu orang anak. Perkawinan yang sudah disertai dengan keberadaan anak memerlukan kerja sama dari pasangan dalam proses pengasuhan. Banyaknya waktu yang dihabiskan untuk mengurus anak dan bantuan yang diberikan oleh pasangan dalam mengurus anak dapat mempengaruhi kepuasan perkawinan yang dimiliki oleh individu. Berdasarkan hasil penelitian sebelumnya, suami yang terlibat aktif dalam tugas rumah tangga dan pengasuhan anak akan dapat meningkatkan kepuasan perkawinan (Simmerman, Blacher, \& Baker, 2001; Feldman, 2000; Perry-Jenkins \& Crouter, 1990). Selain itu, partisipan yang sibuk mengurus anaknya setiap hari cenderung mengalami kesulitan untuk menghitung kebaikan yang ia lakukan.

Dew dan Wilcox (2011) menyatakan bahwa setelah melakukan aktivitas menghitung kebaikan individu menjadi lebih merasa positif terkait apa yang telah ia lakukan kepada pasangannya. Akan tetapi, dalam penelitian ini ditemukan beberapa kasus yang bertentangan dengan pernyataan tersebut. Terdapat beberapa partisipan yang merasa sedih setelah mengingat-ingat kebaikan yang ia berikan kepada pasangannya, karena menyadari 
bahwa perilaku baiknya masih sedikit apabila dibandingkan dengan pasangannya. Munculnya pemikiran tersebut membuat partisipan merasa bahwa dirinya belum cukup baik sebagai pasangan dan menghambat peningkatan kepuasan perkawinannya. Walaupun begitu, terdapat pula partisipan yang justru merasa termotivasi untuk melakukan lebih banyak tindakan baik kepada pasangannya setelah menyadari bahwa tindakan baik yang ia lakukan ke pasangan masih sedikit dan ia pun menjadi lebih giat dalam mencari hal baik lain yang dapat dilakukan kepada pasangannya. Temuan ini sejalan dengan Dew dan Wilcox (2011) yang mengatakan bahwa mengingat kebaikan dapat mendorong individu untuk mencari tahu kesenangan pasangan dan kemudian melakukannya.

Kesesuaian individu dengan aktivitas menghitung kebaikan (personactivity fit) berperan penting dalam penelitian ini. Individu akan lebih berusaha menjalankan aktivitas yang sesuai dengan ketertarikannya dan nilai yang ia percayai (Layous \& Lyubomirsky, 2012), sehingga manfaat yang didapat pun dapat menjadi lebih optimal. Pada penelitian ini, peneliti menduga adanya partisipan yang memiliki perbedaan nilai, sehingga ia tidak mendapatkan manfaat dari aktivitas menghitung kebaikan. Ada partisipan yang merasa segan untuk menghitung kebaikan, karena menurutnya hal tersebut membuat dirinya menjadi perhitungan kepada pasangannya, yang mana pandangan ini dianggap negatif olehnya. Selain itu, ada pula yang merasa segan untuk menghitung kebaikan, karena merasa Tuhan yang berhak untuk menghitung dan membalas kebaikannya.

\section{SIMPULAN}

Berdasarkan hasil penelitian yang telah dilakukan, terdapat dua kesimpulan yang diperoleh, yaitu (1) tidak terdapat perbedaan tingkat kepuasan perkawinan yang signifikan antara kelompok yang melakukan aktivitas menghitung kebaikan dan yang tidak melakukan aktivitas menghitung kebaikan, dan (2) tidak terdapat perbedaan tingkat kepuasan perkawinan yang signifikan antara sebelum dan sesudah melakukan aktivitas menghitung kebaikan.

\section{SARAN}

Aktivitas menghitung kebaikan dapat menjadi alternatif program dalam terapi pasangan atau individu yang memiliki permasalahan perkawinan. Hal tersebut didasarkan pada hasil temuan dalam penelitian ini, dimana partisipan dalam kelompok eksperimen menunjukkan kepuasan perkawinan yang meningkat antara sebelum dan sesudah melakukan aktivitas menghitung kebaikan, walaupun perbedaannya tidak signifikan. Dengan melakukan aktivitas menghitung kebaikan, diharapkan individu dapat meningkatkan hubungannya dengan pasangannya dan memandang hubungannya dengan lebih positif dan bermakna. Selain itu, aktivitas menghitung kebaikan merupakan metode yang masih tergolong baru dalam psikologi postif atau aktivitas positif, sehingga masih dapat dikembangkan lebih lanjut agar nantinya dapat lebih efektif lagi dalam meningkatkan kepuasan perkawinan ataupun variabel lainnya.

\section{DAFTAR PUSTAKA}

Ahangar, K., Juhari, R., Yaacob, S. N., \& Talib, M. A. (2016). Demographic factors and marital satisfaction among Iranian married students in Malaysia. Asian Journal of Social Sciences of Humanities, 5(2), 153-163.

Baumeister, R. F., \& Leary, M. R. (1995). The need to belong: Desire for interpersonal attatchments as a fundamental human motivation. Psychological Bulletin, 117(3), 497-529.

Bolier, L., Haverman, M., Westerhof, G. J., Riper, H., Smit, F., \& Bohlmeijer (2013). Positive psychology interventions: A meta-analysis of randomized controlled studies. BMC Public Health, 13(1), 119138.

Buchanan, K. E., \& Bardi, A. (2010). Acts of 
kindness and acts of novelty affect life satisfaction. The Journal of Social Psychology, 150(3), 235-237.

Dehle, C., \& Weiss, R. L. (1998). Sex differences in prospective associations between marital quality and depressed mood. Journal of Marriage and The Family, 60(4), 1002-1011.

Dew, J., \& Wilcox, W. B. (2011). Give and you shall receive? Generosity, sacrifice, and marital quality. National Marriage Project Working Paper, 11(1), 1-28.

Duffy, K. G., \& Atwater, E. (2005). Psychology for living: Adjustment, growth, and behavior today (8th ed.). New Jersey: Pearson Education.

Duvall, E. R. M., \& Miller, B. C. (1985). Marriage and family development. New York: Harper \& Row.

Emmons, R. A., \& McCullough, M. E. (2003). Counting blessings versus burdens: An experimental investigation of gratitude and subjective wellbeing in daily life. Journal of Personality and Social Psychology, 84(2), 377-389.

Feldman, R. (2000). Parents' convergence on sharing and marital satisfaction, father involvement, and parent-child relationship at the transition to parenthood. Infant Mental Health Journal, 21(3), 176-191.

Fowers, B. J., \& Olson, D. H. (1993). ENRICH Marital Satisfaction Scale: A brief research and clinical tool. Journal of Family psychology, 7(2), 176-185.

Gander, F., Proyer, R. T., Ruch, W., \& Wyss, T. (2013). Strength-based positive interventions: Further evidence for their potential in enhancing well-being and alleviating depression. Journal of Happiness Studies, 14(4), 1241-1259.

Gravetter, F. J. \& Forzano, L. B. (2009). Research methods for the behavioral sciences (4th edition). Canada: Cengage Learning.

Greeff, A. P., \& Bruyne, T. D. (2000). Conflict management style and marital satisfaction. Journal of Sex \& Marital Therapy, 26(4), 321-334.

Juwita, R. (2013). Hubungan antara cinta dan kepuasan perkawinan pada individu pada tahap awal perkawinan. Depok: Fakultas Psikologi, Universitas Indonesia.

Karney, B. R., \& Bradbury, T. N. (1995). The longitudinal course of marital quality and stability: A review of theory, method, and research. Psychological Bulletin, 118(1), 3-34.

Kaslow, F. W., \& Hammerschmidt, H. (1993). Long term "good" marriages: The seemingly essential ingredients. Journal of Couples Therapy, 3(2-3), 15-38.

Kaslow, F., \& Robison, J. A. (1996). Long-term satisfying marriages: Perceptions of contributing factors. American Journal of Family Therapy, 24(2), 153-170.

Kerr, S. L., O'Donovan, A., \& Pepping, C. A. (2015). Can gratitude and kindness interventions enhance well-being in a clinical sample? Journal of Happiness Studies, 16(1), 17-36.

Layous, K., \& Lyubomirsky, S. (2012). The how, why, what, when, and who of happiness: Mechanisms underlying the success of positive interventions. To appear in J. Gruber \& J. Moscowitz (Eds.), The light and dark side of positive emotions. New York: Oxford University Press.

Lyubomirsky, S., \& Layous, K. (2013). How do simple positive activites increase wellbeing? Association for Psychological Science, 22(1), 57-62.

Lyubomirsky, S., King, L., \& Diener, E. (2005). The benefits of frequent positive affect: Does happiness lead to success? Psychological Bulletin, 131(6), 803-855.

Lyubomirsky, S., Sheldon, K. M., \& Schkade, D. (2005). Pursuing happiness: The architecture of sustainable change. Review of General Psychology, 9(2), 111-131.

Miller, P. J., Caughlin, J. P., \& Huston, T. L. (2003). Trait expressiveness and marital satisfaction: The role of idealization processes. Journal of Marriage and Family, 65(4), 978-995.

Olson, D. H. \& DeFrain, J. (2006). Marriage and Families: Intimacy, Diversity, and Strengths (5th ed). New York: McGraw Hill.

Otake, K., Shimai, S., Matsumi, J. T., Otsui, K., \& Fredrickson, B. L. (2006). Happy people become happier through kindness: A counting kindness intervention. Journal of Happiness Studies, 7, 361375.

Pasch, L. A., \& Bradbury, T. N. (1998). Social support, conflict, and the development of marital dysfunction. Journal of 
consulting and clinical psychology, 66(2), 219-230.

Perry-Jenkins, M., \& Crouter, A. C. (1990). Men's Provider-Role Attitudes Implications for Household Work and Marital Satisfaction. Journal of Family Issues, 11(2), 136-156.

Peterson, C., \& Seligman, M. E. P. (2004).

Character strengths and virtues: A

handbook and classification.

Washington, DC: Oxford University

Press.

Prasetya, B. E. A. (2001). Usia kronologis dan usia pernikahan sebagai prediktor kepuasan pernikahan pada kaum istri di metro Manila. Anima, Indonesian Psychological Journal, 22(2), 101-107.

Rollins, B. C., \& Feldman, H. (1970). Marital satisfaction over the family life cycle. Journal of Marriage and the Family, 32(1), 20-28.

Ross, C. E., Mirowsky, J., \& Goldsteen, K. (1990). The impact of the family on health: The decade in review. Journal of Marriage and Family, 52(4), 1059.

Seligman, M. E., Steen, T. A., Park, N., \& Peterson, C. (2005). Positive psychology progress. American Psychologist, 60(5), 410-421.

Sheldon, K. M., \& Lyubomirsky, S. (2006). How to increase and sustain positive emotion: The effects of expressing gratitude and visualizing best possible selves. The Journal of Positive Psychology, 1(2), 73-82.

Simmerman, S., Blacher, J., \& Baker, B. L. (2001). Fathers' and mothers' perceptions of father involvement in families with young children with a disability. Journal of Intellectual and Developmental Disability, 26(4), 325338.

Sin, N. L., \& Lyubomirsky, S. (2009). Enhancing well-being and alleviating depressive symptoms with positive psychology interventions: A practicefriendly meta-analysis. Journal of Clinical Psychology, 65(5), 467-487.

Stone, E., \& Shackelford, T. (2007). In R. F. Baumeister \& K. D. Vohs (Eds.), Encyclopedia of social psychology. Thousand Oaks, CA: Sage. 